\title{
Yerli Ziyaretçilerin Ilgaz Dağı Destinasyonunu Tekrar Ziyaret Etme Niyetleri Üzerine Bir Araştırma ${ }^{1}$
}

\author{
Aydoğan Aydoğdu $\mathrm{u}^{\mathrm{a}^{*}}$, Yusuf Ziya Koçb, Dilara Eylül Koçc \\ a,cKastamonu Üniversitesi, Turizm Fakültesi, Kastamonu.
}

${ }^{b}$ Kastamonu Üniversitesi, Sosyal Bilimler Enstitüsü Yüksek Lisans Öğrencisi, Kastamonu.

\section{$\ddot{\partial} z$}

Her geçen gün gelişmekte olan turizm sektörü içerisinde önemli bir yere sahip olan Kı̧̧ Turizmi özellikle gelir seviyesi yüksek turistler tarafından tercih edilmektedir. Kış Turizmi kapsaminda yapılan rekreasyon faaliyetlerinin başında ise kayak gelmektedir. Ülkemizde kayak yapılacak seçenekler arasında Ilgaz Dağı Milli Parkı sınırları içerisinde yer alan Ilgaz Kayak Merkezi de yer almaktadır. Ilgaz Kayak Merkezi'nin yamaç eğimi, telesiyejin beklentiyi karşılaması, kayak ekipmanlarının kolay ve uygun fiyata temin edilebilmesi, kayak merkezinde bulunan rekreasyon tesislerinin ve konaklama işletmelerinin yeterliliği Ilgaz Kayak Merkezi'ni ziyaret eden yerli turistlerin memnuniyetleri açısından önem arz etmektedir. Turistik deneyimlerinde doyuma ulaşmış turistler, o destinasyonu tekrar ziyaret etme eğilimi gösterecek ve yakın çevrelerine ziyaret etmeleri konusunda olumlu tavsiyelerde bulunacaklardır. Bu bağlamda çalı̧manın amacı Ilgaz Kayak Merkezi'ni ziyaret eden bireylerin doyumunu belirleyen etmenlerin, genel tatil doyumlarmin, Ilgaz Kayak Merkezi'ni tekrar ziyaret etme ve başkalarma tavsiye etme konularındaki tutumlarının ortaya konmasıdır. Araştırma amaçlarına ulaşabilmek için öncelikle ilgili yazın derinlemesine taranmıştır. Elde edilen ikincil verilerin yardımıyla bir anket formu hazırlanmıştır. Ilgaz Kayak Merkezi'ni ziyaret eden yerli turistlerden kolayda, yargısal ve gönüllülü̈k yaklaşımlarının birlikte işe koşulduğu bir örneklem oluşturulmuştur. Yüz yüze görüşmelerin yanı sıra bırak topla yaklaşımları ile veriler toplanmıştır. Demografik yapıyla ilgili veriler sıklik ve yüzdelerle, ziyaretçi memnuniyeti ve tekrar ziyaret etme eğilimleri ile ilgili veriler ise sosyal bilimlerde yaygın kullamılan bir istatistik paket programı aracilğ̆ıyla çözümlenmiştir. Çözümlemelerde aritmetik ortalama ve faktör analizi gibi istatiksel analiz yöntemlerinden faydalanmıştır. Yapılan faktör analizi sonucunda konukların doyumlarım belirleyen dört boyutlu bir yap elde edilmiş ve kayak olanakları, rekreasyon olanakları, ürün ve hizmet kalitesi, erişilebilirlik olarak adlandırılmıştır. Araştırma bulguları Ilgaz Kayak Merkezi'ni ziyaret eden yerli turistlerin kayak olanaklarından, konaklama ve yiyecek-içecek işletmelerinin sunmuş olduğu ürün ve hizmetlerden genel olarak memnun kaldıkları, buna karşın alışveriş olanaklarından memnun kalmadıklarımı ortaya koymuştur. Araştırmada ayrıca yerli turistlerin büyük oranının Ilgaz Kayak Merkezi'ni tekrar ziyaret etme ve arkadaşlarına tavsiye etme konularmda çok istekli oldukları saptanmıştır.

Anahtar Kelimeler: Ziyaretçi Doyumu, Tekrar Ziyaret Etme Niyeti, Kış Turizmi, Ilgaz Kayak Merkezi

\footnotetext{
${ }^{1}$ Bu çalışma 20-22 Nisan 2017 Tarihleri arasında Bişkek'te düzenlenmiş olan III. Uluslararası Türk Dünyası Turizm Sempozyumu'nda sözlü bildiri olarak sunulmuş olup, gözden geçirilerek genişletilmiştir.
} 


\title{
A Research on Revisit Intention of Local Tourists to Ilgaz Mountain Destination
}

\begin{abstract}
Winter tourism, which has an important place in the developing tourism sector each passing day, is especially preferred by high income level tourists. Skiing is the most preferred recreational activity in the context of winter tourism. Ilgaz Ski Centre, which is located within the boundaries of Ilgaz Mountain National Park within the borders of Kastamonu and Çankır provinces, is also one of the main places to ski in Turkey. Ilgaz ski center's incline of slope, sufficient recreational activities and accommodation facilities in and around the ski centre, satisfaction from chair lift, availability and reasonable price of the ski equipment are important for satisfaction of local tourists visiting Ilgaz ski centre. Satisfaction will increase the revisit intention of tourists and they will recommend the destination to their relations. The aim of this study is to reveal the factors determining the satisfaction of people visiting the Ilgaz mountain ski resort and examining their holiday satisfaction and attitudes towards revisiting the destination. In order to reach research purposes, firstly, an in-depth literature research was conducted. A questionnaire form was prepared using the secondary data. A sample was constituted from local tourists visiting Ilgaz ski centre. In the sample, convenience sampling method, judicatory and volunteering approaches were used. The data were collected by face-to-face interviews and also "drop and collect" approach. Data on demographic structure were analyzed by frequency and percentage and data on visitor satisfaction and revisit intentions were analyzed by a statistical package program commonly used in social sciences. Statistical methods such as arithmetic mean and factor analysis were used in the analyzes. As a result of factor analysis, a four-dimensional structure that determines the satisfaction of the guests has been obtained and these dimensions were called skiing facilities, recreation facilities, product and service quality, accessibility. The results reveal that although local tourists visiting Ilgaz Ski Centre were generally satisfied with ski facilities and the products and services offered by accommodation and food and beverage enterprises, they were not satisfied with shopping facilities. The results of this study also showed that a great majority of local tourists were enthusiastic about revisiting Ilgaz Ski Resort and recommend it to other people.
\end{abstract}

Keywords: Visitor Satisfaction, Intention to revisit, Winter Tourism, Ilgaz Ski Resort.

\section{GİRIŞ}

Yol açmış olduğu ekonomik, sosyal, kültürel, çevresel ve politik etkiler nedeniyle turizm, günümüzün en önemli olgusu haline gelmiştir. Nitekim Birlemiş Milletler Dünya Turizm Örgütü (United Nations World Tourism Organization [UNWTO]) verilerine göre denizaşırı turizm hareketlerine katılan bireylerin sayısı 2017 yılında bir önceki yıla oranla \% 7'lik bir artışla 1 Milyar 322 Milyon kişiye ulaşmıştır. Henüz ekonomik büyüklüklerin netleşmediği 2017 yılı Dünya turizmi açısından olağanüstü bir artışın yaşandığı yıl olarak kayıtlara geçerken 2018 yılında da bu hareketliliğin \% 4 oranında bir artışla devam etmesi beklenmektedir (UNWTO, 2018). Diğer yandan 2016 yılı sonu itibarıla turizm etkinliklerinin Dünya ölçeğinde yaratmış olduğu ekonomik büyüklük döviz kuru farkları ve enflasyondan arındırılmış değerlerle 1 trilyon 220 milyar dolar olarak gerçekleşmiştir (UNWTO, 2017).

Turizm etkinlerinin sağlamış olduğu ekonomik kazanımlar önceleri gelişmemiş ve gelişmekte olan ülkeler için önemliyken özellikle 2009 ekonomik krizinden sonra 
gelişmiş ülkeler için de önemli bir olgu haline gelmiştir. Nitekim uyguladıkları katı vize kurallarıla bilenen İngiltere, Fransa, Almanya gibi ülkeler turizmin sağlamış olduğu döviz kazandırıcı etkilerin ve istihdam olanaklarının cazibesine kapılarak vize rejimlerinde değişime gitmişler ve görece daha hafif olarak nitelendirecek uygulamaları hayata geçirmişlerdir (Aydoğdu, Çitoğlu ve Bayraktar, 2016). Sahip olunan yapısal sorunların aşılmasında turizmin bir çıkış noktası olarak hemen her ülke tarafından benimsenmesi Dünya ölçeğinde ülkeler arasında çetin bir rekabete yol açmıştır. Günümüzde bu rekabete metropol şehirlerin, hatta aynı ülkeden küçük yerleşkelerin de katılmaya başladı̆̆ı görülmektedir.

Ülkeler ve şehirlerarasında yaşanan rekabetten başat çıkabilmek için çok farklı stratejiler uygulanmaktadır. Bu stratejiler içerisinde turizm etkinliklerinin doğasından kaynaklanan (örneğin; mevsimsellik, dönemsel işsizlik vb.) bazı olumsuzlukları bertaraf etmek için ülkelerin ve şehirlerin sahip oldukları doğal, tarihi ve kültürel verileri kullanarak ürün çeşitlendirmesi yaklaşımını odağa yerleştirdikleri görülmektedir. Doğa ve doğaya yönelik turizm etkinlikleri bu çeşitlendirme stratejisinde öne çıkmakta ve potansiyel talebin ülke, bölge ve/ya turistik varış noktasına çekebilmesinden doğal çekiciliklerden yoğun olarak faydalanmaktadırlar (Güzel, 2010; Aydoğdu vd., 2016). Ürün çeşitlendirme çabaları kapsamında niş pazar yaratma kapasitesi yüksek olan doğaya dayalı turizm etkinliklerinin önceliklendirilmesinin turizmden elde edilen kazanımların maksimize edilmesi açısından önemli olduğuna inanılmaktadır (Kaşlı, İlban ve Şahin, 2009). Nitekim golf turizmi, av turizmi, gastronomi ve kayak turizmi gibi türlerin diğer turizm çeşitlerine göre daha yüksek katma değer yaratma potansiyeli olduğu hususunda geniş bir uzlaşı vardır (Ahvenainen, 2013; Burakowski \& Magnusson, 2012; Ski Canada, 2015).

Diğer yandan rekabetten başat çıkma çabasında olan ülkelerde ve diğer turistik varış noktalarında sunulan ürün ve hizmetlerin konukların beklentilerini de aşarak koşulsuz bir memnuniyet sağlaması gerekmektedir. Çünkü başarılı bir varış noktası pazarlaması için ziyaretçi memnuniyeti oldukça önemli bir rol oynamaktadır. Bu nedenle ziyaretçilerin varış noktasından her açıdan memnun ayrılmalarını sağlamak gerekmektedir (Arat, Karaman ve Harbali, 2015; Işın, 2012; Şirin ve Aksu, 2016). Bu durum olumlu ve güçlü bir varış noktası imajının oluşturulmasında önemli bir etken olarak ortaya çıkmaktadır (Duman ve Öztürk, 2005; Yoon \& Uysal, 2005; Mcdowall \& Ma, 2010; Albayrak ve Caber, 2011).

Kastamonu Osmanlı İmparatorluğu dönemindeki ekonomik, sosyal, kültürel ve politik açıdan görkemli günlerinden çok uzak olup birçok yapısal sorunla karşı karşıyadır. İl topraklarının engebeli, çok parçalı ve küçük arazi parçalarından oluşması, il genelinde hüküm süren karasal mevsim ve benzeri koşullar katma değeri yüksek tarım ürünlerinin elde edilmesini olanaksız kılmaktadır. Bu nedenlerle Kastamonu Cumhuriyetin ilanından günümüze genç ve girişimci nüfusunu büyük şehirlere göç yoluyla vermiştir. Sayılan bu etmenlere bir de ulaşım sorunlarının eklenmesiyle il Sosyo Ekonomik Gelişmişlik Endeksi (SEGE) sıralamasında 47.sıraya gerilemiştir (Kalkınma Bakanlığı, 2013). 
Tüm bu anlatılanlara karşın Kastamonu, sahip olduğu doğal güzellikler, iklimsel koşullar, somut ve somut olmayan miras vb. etmenlerle dört mevsim turizm etkinliğinin yapılabileceği ender varış noktalarından biridir (Aydoğdu,2012). Kastamonu'da gerek siyasal gerekse de sivil toplum ve kanaat önderlerinin kentin makûs kaderinin turizmle aşılabileceği konusunda bir uzlaşı içerisinde oldukları görülmektedir. Böylesi bir inanç, son yıllarda marka bir varış noktası olmak adına ilde örgütlü çabaları da beraberinde getirmiştir. Vali, belediye başkanı, meslek odası başkanları ve sivil toplum örgütleri bu çabalara çok yönlü katkılar sağlamaktadırlar. Örneğin belediye ildeki tarihi konakları satın almakta, restore etmekte ve yap-işletdevret yöntemiyle kiraya vermektedir (Kastamonu Belediyesi, 2015). Valilik belediyenin geliştirmiş olduğu sokak sağlıklaştırma çabalarına il özel dairesi bütçesinden kaynak aktarmakta böylelikle il merkezinde turizm için alt ve üst yapı büyük ölçüde tamamlanmaktadır. Bununla birlikte Kastamonu'nun marka bir varış yeri olması için sayılan çabalar yeterli değildir. Hedeflenen marka varış noktası olma hedefinin en önemli koşulu turistlerin ziyaretleri sırasında aldıkları ürün ve hizmetlerden duymuş oldukları doyumun en üst seviyeye ulaşması olduğuna inanılmaktadır.

Anlatılanlar bağlamında araştırmanın amacı, Kastamonu turizmi için yaşamsal bir önem taşıyan Ilgaz Dağı Milli Parkı kayak merkezinde sunulan ürün ve hizmetlere ilişkin tüketici doyumunun ölçülmesidir. Ayrıca Ilgaz Dağı Milli Parkı'nı ziyaret edenlerin yeniden ziyaret ve başkalarına tavsiye etme konularında isteklilikleri ve ziyaretçilerin profilleri de saptanmak istenmiştir.

Anlatılanlar ışığında araştırmada aşağıdaki soruların yanıtları aranmaktadır:

- Ilgaz Kayak Merkezi'ni ziyaret edenlerin yeme-içme olanaklarından doyum düzeyleri nedir?

- Ilgaz Kayak Merkezi'ni ziyaret edenlerin konaklama olanaklarından doyum düzeyleri nedir?

- Ilgaz Kayak Merkezi'ni ziyaret edenlerin rekreasyon olanaklardan doyum düzeyleri nedir?

- Ilgaz Kayak Merkezi'ni ziyaret edenlerin genel doyum düzeyleri nedir?

Araştırmada ayrıca yukarında sayılanların yanı sıra Ilgaz Kayak Merkezi'ni ziyaret eden yerli turistlerin doyumuna etki eden etmenler faktör analizi yapılarak indirgenmiş boyutlarıyla ortaya konmak istenmiştir.

\section{LITERATÜR TARAMASI}

Turistik varış noktaları hem yatırımcılar hem de ziyaretçiler açısından çekici hale getirilmesi gereken (bölge, eyalet, ülke, şehir vb.) coğrafi alanlardan olup turizmin gelişimi açısından büyük önem taşımaktadırlar (Ritchie \& Crouch, 2000). Turistik varış noktalarında sunulan ürün ve hizmet kalitesi turizmin gelişimi ve müşteri doyumu için sürekli arttırılması gereken stratejik önemde bir olgudur. Turizm endüstrisinde hizmet kalitesi kavramı ziyaretçilere hizmet çeşitliliği sunarak rakip varış noktalarıyla rekabet etmek isteyen yöneticiler için de giderek artan bir öneme sahip olmuştur. 
Ziyaretçi beklentilerine göre sunulan hizmet özelliklerini geliştirmeye ve bu yolla hizmet kalitesini artırmaya öncelik verilmelidir (Saltık, 2016).

Turizm endüstrisinde ziyaretçi davranışına yönelik araştırmalar turistik ürün ve hizmetlerin satın alınmasından sonraki sürecin temelinde ziyaretçi doyumu olduğuna işaret etmektedir. Ziyaretçi doyumu, tüketicinin tüketim öncesi beklentileri ile tüketim sonrası duygularının değerlendirilmesinin bir birleşimi olarak görülmektedir. Bu bağlamda doyum kavramı "memnuniyet" olarak da tanımlanabilmekte (Aydoğdu, 2005) ve genel anlamda "tüketicinin aldiğı mal veya hizmetten tatmin olma durumu"nu yansitmaktadır (Oliver, 1980; Millan \& Esteban, 2004; Aydoğdu, 2005; Duman ve Öztürk, 2005; Piercy \& Ellinger, 2015). Bu bakımdan ziyaretçilerin turizm varış noktalarından beklentileri ile satın aldıkları ürün ya da hizmet arasındaki bağlantı ziyaretçilerin doyum düzeylerini belirlemektedir. Bir ziyaretçi geçmişte tercih etmiş olduğu bir varış noktasından olumlu deneyimler elde etmişse, gelecekte yine aynı varış noktasını tercih etme eğiliminde olacaktır (Anderson \& Sullivan, 1993; Fuller, Wilde, Hanlan \& Mason, 2007).

Turizm işletmelerinin temel amaçları kâr elde etmek ve faaliyetlerini sürdürebilmektir. Bu nedenle, turizm işletmelerinin ayakta kalabilmelerinin temel koşulu tüketici doyumunu sağlamalarıdır. Misafir doyumu sağlamak için turizm işletmeleri toplam hizmet kalitesini yükselterek ziyaretçilerin tekrar ziyaret etme ve başkalarına tavsiye etme niyetlerini arttırabilmektedirler. Böylelikle ziyaretçi doyumu kârlılık, pazar payı ve yatırımın geri dönüşü gibi önemli konularda artışı da beraberinde getirmektedir (Kılıçhan, 2012; Ekiz ve Ölçer,2016).

Diğer yandan turizm işletmeleri faaliyetlerini çok hızlı değişen koşullarda devam ettirmektedirler. Yaşanılan değişime karşı işletmeler sürekli kendilerini yeniliğe zorlamalı ve yoğun rekabetle başa çıkmanın yollarını aramalıdırlar. Bundan dolayı işletmeler varlıklarını sürdürebilmek için hem çevre değişikliklerini önceden görmek hem de güçlü rekabet ortamında üstünlük sağlamak zorundadırlar. Bu durum rekabet etme gücüne ve üstünlügüne bağlı görünmektedir. Günümüzde işletmeler arasında rekabet avantajı sağlamanın temel şartı işletmeler için doğru stratejileri belirlemektir. Rekabete dayalı ekonomik ortamda strateji; yeniliği, ilerlemeyi, çevre ile uyum içinde olmayı sağlayarak, meydana gelen değişiklikleri kontrol etme amacındadır (Arslan, 2008). Rekabet kavramı, "müşsterileri işletmelerin kendilerine sunduğu mal ve hizmetleri alternatifleri karşısında tercih etmesini sürdürülebilir bir biçimde sağlayabilme yeteneği ve gücü" olduğu görüşü yaygın olarak kabul edilmektedir. Bütün işletmelerde olduğu gibi turizm işletmelerinde de hedef pazarın istek ve ihtiyaçlarının neler olduğunu anlamak rekabet üstünlügü sağlamak açısından önem arz etmektedir. Belirlenen bu istek ve ihtiyaçları karşılamaya ve hatta beklentilerin aşılmasına yönelik stratejiler geliştirilerek bir varış yeri rekabet avantajını elinde tutabilmektedir. Şayet geliştirilmesi gereken stratejiler de hizmet kalitesi ve müşteri memnuniyeti konularını kapsıyorsa, bu konular güvenilir bir şekilde değerlendirilmeli ve ölçülmelidir (Ekiz ve Ölçer, 2016; Zengin ve Bilgiçli, 2016). Ayrıca işletmelerin hizmet kalitesini, müşteri memnuniyetini, müşteri sadakatini bunun sonucunda işletmelerin rekabet üstünlüğünü ve performansını belirleme açısından insan unsurunun yani ziyaretçilerle etkileşim içinde 
olan çalışanların önemli olduğu kabul görmektedir (Kuşluvan ve Eren, 2011; Çakıcı ve Özdamar, 2016; Aydoğdu, 2005, 2016).

Turizm işletmelerinin orta ve uzun vadede sürdürülebilir olması da yine işletmelerin rakiplerine kıyasla sahip oldukları yeteneklere bağlıdır. Bu yeteneklerden işletmenin yönetim özellikleri, AR-GE faaliyetleri gibi faktörleri saymak mümkündür. Ayrıca, rekabet üstünlüğünün sürdürülebilmesi için düşük fiyat, yüksek kalite, müşterinin hızla değişen gereksinimlerine uygun ürünlerin üretilmesi gibi faktörler açısından da büyük bir öneme sahiptir (Zengin ve Bilgiçli, 2016).

\section{YÖNTEM}

Bu bölümde araştırmanın kapsamı, tasarım türü, kaynağı, nüfusu (tanımlanmış evren ya da ana kütle), örneklemi, modeli ve yöntemi, veri toplama tekniği ve aracı, araştırmanın süresi, analiz yöntemi, güvenirlik ve geçerlik konuları açıklanmaktadır.

Çalışmada Ilgaz Dağı Milli Parkı Kayak Merkezi'ni ziyaret eden yerli turistlerin ziyaretleri süresince almış oldukları ürün ve hizmetlerden duymuş oldukları doyum ve bu doyumu belirleyen etmenlerle, merkezi yeniden ziyaret ve başkalarına önerme konularındaki isteklilikleri araştırma konusu olarak seçilmiştir.

\subsection{Araştırmanın Kapsamı}

Araştırma birbiri ile ilişkili 4 ana sorunu çözmek için tasarlandı. Öncelikle Ilgaz Kayak Merkezi (IKM)'ni ziyaret eden yerli turistlerin merkezde sunulan başta konaklama, yeme-içme, kayak sporu olanakları, alışveriş ve diğer olanaklardan tüketim ve/ya ziyaret sonrası duymuş oldukları doyum ölçülmek istenmiş olup, bu hususlar araştırmanın öncelikli kapsamını oluşturmaktadır. Bununla birlikte araştırma örnekleminde yer alan bireylerin doyumlarına koşut Ilgaz Kayak Merkezi'ni yeniden ziyaret etme ve başkalarına önerme konularındaki istekliliklerinin ortaya konması, araştırmanın kapsamında yer alan diğer iki husus olarak ifade edilebilir. Gerek yeniden ziyaret, gerekse de başkalarına önerme, mikro anlamda işletme yöneticileri, makro anlamda ise destinasyon yönetimlerinin öncelikli konuları arasında yer alan olgulardır. Bu nedenle gelecek pazarlama çabalarını kolaylaştırması ve ilgili paydaşlara hazır veri sağlayacak olması inancıyla ziyaretçilerin profilleri ve doyuma etki eden etmenlerin özünü temel alan değişkenlerin saptanması da araştırmanın kapsamı içerisine alınmıştır.

\subsection{Araştırmanın Modeli ve Tasarımı}

Araştırmanın kapsam ve amacına ve bunlara koşut belirlenmiş olan araştırma sorularına geçerli ve güvenilir yanıtlar sağlayacak yöntem "Tarama"dır. Bu nedenle araştırmada "Tarama Modeli" işe koşulmuştur. Tarama Modelleri geçmişte ya da halen var olan bir durumu olduğu şekliyle betimlemeyi amaçlayan araştırma yaklaşımlarıdır. Modelde araştırmaya konu olay, birey ya da nesne kendi koşulları içinde olduğu gibi tanımlanmaya çalışılır. Onları herhangi bir şekilde değiştirme ve/ya etkileme çabası gösterilmez. Başka bir deyişle var olan durum olduğu gibi ortaya konur (Karasar, 2005). Tarama Modeli'nde bilimin gözleme, kaydetme, olaylar arasındaki ilişkileri 
saptama, kontrol edilen değişmez ilişkiler üzerinde genellemelere varma amaçları vardır. Bir başka ifadeyle bilimin tasvir işlevi ön plandadır (Yıldırım, 1966).

Anlatılanlar 1şığında araştırmada işe koşulan modelin bir "İlişkisel Tarama Modeli" olduğunu söylemek olanaklıdır. Modelle araştırma sorularına geçerli ve güvenilir çözümler bulabilmek amacıyla öncelikle ilgili yazın derinlemesine aranmış ve elde edilen ikincil verilerin yardımıyla bir ölçek geliştirilmiştir. Geliştirilen ölçek (anket) kolayda ve gönüllülük yaklaşımlarıyla belirlenmiş katılımcılara yüz-yüze görüşmelerin yanı sıra bırak topla yaklaşımlarıyla uygulanmıştır.

Araştırmada, ortaya konmak istenenleri sağlayacak durum, görüş ve tutumları saptamak amacıyla geliştirilen ölçek iki bölümden oluşturulmuştur. Birinci bölümde katılımcların Ilgaz Kayak Merkezi (IKM)'nde almış oldukları ürün ve hizmetlerden duymuş oldukları doyumu ölçmeye yönelik beşli Likert tipi ölçeğe göre hazırlanmış 15 ifade yer almıştır. Birinci bölümde ayrıca görüşüne başvurulan katılımcıların almış oldukları ürün ve hizmetlerden duymuş oldukları doyum ya da doyumsuzluk sonucu genel memnuniyetlerini veya memnuniyetsizliklerini, IKM'ni yeniden ziyaret ve başkalarına önerme konularındaki istekliliklerini ölçmek amacıyla altı adet bağımlı değişkene yer verilmiştir. Bu değişkenler de beşli Likert tipi ölçeğe göre geliştirilmiş olup bağımsız değişkenlerin ziyaretçilerde oluşturduğu tutumu ölçmektedir. İkinci bölümde ise katılımcıların profillerini ortaya koymaya yönelik demografik sorulara yer verilmiştir. Bu sorular temel olarak isimsel ve sıralama ölçekleri ile hazırlanmış soru ifadelerinden oluşmuştur.

\subsection{Araştırmanın Kaynağı, Nüfusu, Örneklemi ve Süresi}

Ilgaz Kayak Merkezi'ni ziyaret eden yerli turistler araştırmada görüşüne başvurulan katılımcıların kaynağını oluşturmuştur. Araştırma örneklemi ise 2016-2017 eğitim öğretim yılı sömestre tatilinde konaklamalı olarak Ilgaz Kayak Merkezi'ni ziyaret eden ve bir konaklama tesisinde kalan konuklarda kolayda ve gönüllülük esasına göre belirlenmiş olan 214 kişidir. Araştırmaya bırak topla yöntemi ile katılan bazı tatilcilerin anket formunda yer alan tüm sorulara yanıt vermemiş olmalarından dolayı 202 adet anket formu değerlendirilmiştir.

Araştırma sürecinde veriler 28 Ocak ila 05 Şubat 2017 tarihleri arasında ziyaretçilerin yoğun olarak bulundukları otel lobi ve kafeteryaları, kayak kiralama merkezleri, telesiyej girişleri gibi yerlerde gönüllülük esasına göre yürütülen yüz-yüze görüşmelerin yanı sıra otel odaları gibi mekânlara bırak topla yöntemi ile toplanmıştır.

\subsection{Araştırmanın Sınırlılıkları}

Araştırma 2016-2017 eğitim ve öğretim yılı sömestre tatilinin ikinci haftası süresinde (28 Ocak-05 Şubat 2017) IKM'nde yürütülmüştür. Bu nedenle kış sezonunun diğer bölümlerinde merkezde konaklamış olan yerli konukların araştırmada yer almıyor olması araştırmanın önemli kısıtlarından bir tanesidir. Anılan süreçte araştırmanın örneklemine yalnızca Türk konuklar alınmış olup diğer uluslardan turistler araştırma örneklemi dışında bırakılmıştır. Bu da araştırmanın bir diğer kısıtı olarak değerlendirilebilir. 


\subsection{Araştırmanın Veri Toplama Aracı ve Tekniği}

Çalışmada veri toplama aracı olarak anket formları kullanılmıştır. Anket formunun geliştirilmesinde öncelikle ilgili yazın derinlemesine taranmış ve elde edilen bilgiler 1şığında bir ölçek geliştirilmiştir.

Anket formunun birinci bölümünde katılımcıların IKM'nde almış oldukları konaklama, yeme-içme, alışveriş olanakları vb. ürün ve hizmetlerle ilgili doyumları ölçmek amaciyla oluşturulmuş on beş adet bağımsız değişken (ifade) yer almıştır. Bu ifadeler tamamen katılıyorum $=5$, hiç katılmıyorum $=1$, biçiminde beşli Likert tipi ölçeğe göre hazırlanmıştır. Bu ifadeleri IKM'de alınan ürün ve hizmet gruplarından alınan doyumu saptamaya yönelik altı adet bağımlı değişken izlemiştir. Bağımlı değişkenler de tıpkı bağımsız değişkenler gibi beşli Likert tipi ölçeği ile hazırlanmışlardır. Bu bölümde ayrıca katılımcıların duygu ve düşüncelerini özgürce ifade edebilecekleri bir olanak da tanınmıştır. İsimsel ve sıralama ölçeklerinin ağırlıklı kullanıldığı ikinci bölümde 6 adet soru vardır.

Anket çalışması, konukların kafeterya, restoran, lobi, kayak evi, telesiyej giriş ve çıkışları gibi yoğun olarak bulundukları mekânlarda yargısal biçimde belirlenmiş bir yaklaşımla gönüllülük esasının temel alındığı bir teknikle yüz-yüze görüşmeler biçiminde yürütülmüştür. Ayrıca konaklama tesislerinin yönetimlerinden izin alınarak konuk odalarına konulmuş olan anket formları bırak-topla yaklaşımı ile de doldurulmalarına olanak sağlanmıştır.

\subsection{Araştırmanın Analiz Yöntemi}

Çalışma sürecinde anket tekniği ile elde edilen veriler niteliklerine göre çözümlenmiştir. Katılımcıların demografik bilgilerini elde etmeye yönelik hazırlanmış olan kategorik değişkenler sıklık ve yüzdelerle çözümlenmiştir. Doyum belirlemeye yönelik beşli Likert tipi ölçeğe göre hazırlanmış bağımsız ve bağımlı değişkenlerin yer aldığ1 ifadeler ise aritmetik ortalama, standart sapma ve faktör analizi ile çözümlenmiştir.

Faktör analizi, birbiriyle ilişkili çok sayıda değişkeni bir araya getirerek az sayıda kavramsal olarak anlamlı yeni değişkenler (faktörler veya boyutlar) bulmayı keşfetmeyi amaçlayan çok değişkenli bir istatistik olarak tanımlanabilir (Büyüköztürk, 2002). Açıklayıcı (keşifsel) ve doğrulayıcı olmak üzere iki farklı biçimde yapılabilen faktör analizi bu çalışmada işe koşulan ölçeğin araştırmacılar tarafından geliştirilmiş olması nedeniyle açıklayıcı (keşifsel) olarak uygulanmıştır. Faktör analizi ile katılımcıların IKM'nde sunulan ürün ve hizmetlerle ilişkili doyumları daha az sayıda değişkenle ortaya konmuştur. Bu bölümde ayrıca güvenirlik düzeyi için Cronbach's Alfa hesaplaması yapılmıştır. Tüm çözümlemeler (analizler) için Sosyal Bilimler'de yaygın olarak kullanılan bir istatistik paket programının 22. sürümünden yararlanılmıştır. Elde edilen bulgular izleyen alt başlıkta detaylı olarak verilmiştir. 


\section{BULGULAR}

Araştırmaya 214 gönüllü birey katılmış olup 202 anket formu değerlendirmeye alınmıştır. Araştırmaya katılan örneklemle ilgili demografik bulgular Tablo 1'de verilmiştir.

Tablo 1. Katılımcıların Demografik Bilgileri

\begin{tabular}{|c|c|c|c|c|c|c|c|}
\hline Değişkenler & & Erkek & $\%$ & Kadın & $\%$ & Toplam & Toplam \% \\
\hline Cinsiyet & & 90 & 44,50 & 112 & 55,50 & 202 & 100 \\
\hline \multirow{5}{*}{ 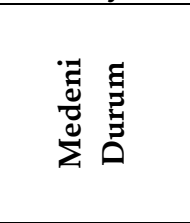 } & Evli & 57 & 28 & 65 & 32 & 122 & 60,4 \\
\hline & Bekâr & 22 & 11 & 27 & 13,6 & 49 & 24,25 \\
\hline & Boşanmış & 7 & 3,4 & 17 & 8,4 & 24 & 11,88 \\
\hline & Ayrı Yaşayan & 1 & 0,5 & 4 & 1,9 & 5 & 2,5 \\
\hline & Yanitsiz & & & & & 2 & 1 \\
\hline \multicolumn{2}{|c|}{ Medeni Durum Toplamı } & 87 & 43 & 113 & 56 & & $202 / 100$ \\
\hline \multirow{7}{*}{ શ્ર } & $18-24$ & 13 & 6,43 & 18 & 8,91 & 31 & 15,35 \\
\hline & $25-34$ & 15 & 7,43 & 20 & 9,90 & 35 & 17,33 \\
\hline & $35-44$ & 26 & 12,87 & 38 & 18,81 & 64 & 31,67 \\
\hline & $45-54$ & 20 & 9,90 & 22 & 10,89 & 42 & 20,80 \\
\hline & $55-64$ & 11 & 5,44 & 7 & 3,47 & 18 & 8,91 \\
\hline & +65 & 5 & 2,48 & 5 & 2,48 & 10 & 4,95 \\
\hline & Yanitsiz & & & & & 2 & 1 \\
\hline \multicolumn{2}{|l|}{ Yaş Toplamı } & 90 & 44,54 & 110 & 54,46 & 202 & 100 \\
\hline \multirow{7}{*}{ 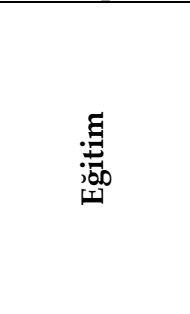 } & Ortaokul & 8 & 3,96 & 8 & 3,96 & 16 & 7,92 \\
\hline & Lise & 30 & 14,85 & 23 & 11,39 & 53 & 26,24 \\
\hline & Önlisans & 10 & 4,95 & 16 & 7,92 & 26 & 12,88 \\
\hline & Lisans & 27 & 13,37 & 46 & 22,78 & 73 & 36,14 \\
\hline & Y. Lisans & 11 & 5,45 & 14 & 6,93 & 25 & 12,38 \\
\hline & Doktora & 2 & 1 & 4 & 1,98 & 6 & 2,97 \\
\hline & Yanitsiz & & & & & 3 & 1,49 \\
\hline \multicolumn{2}{|c|}{ Eğitim Toplamı } & 68 & 43,58 & 111 & 54,96 & 202 & 100 \\
\hline \multirow{8}{*}{ 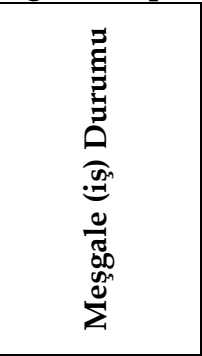 } & Memur & 7 & 3,47 & 22 & 10,89 & 29 & 14,36 \\
\hline & İşçi & 15 & 7,43 & 8 & 3,96 & 23 & 11,39 \\
\hline & Serbest Meslek & 33 & 16,34 & 21 & 10,34 & 54 & 26,73 \\
\hline & Emekli & 21 & 10,40 & 17 & 8,42 & 38 & 18,81 \\
\hline & İşsiz & 1 & 0,5 & 4 & 1,98 & 5 & 2,48 \\
\hline & Diğer & 4 & 1,98 & 19 & 9,40 & 23 & 11,39 \\
\hline & Öğrenci & 8 & 3,96 & 8 & 3,96 & 16 & 7,92 \\
\hline & Yanitsiz & & & & & 14 & 6,93 \\
\hline \multicolumn{2}{|c|}{ Meşgale Toplamı } & 89 & 44,08 & 99 & 48,95 & 202 & 100 \\
\hline \multicolumn{2}{|c|}{ Değişkenler } & Erkek & $\%$ & Kadın & $\%$ & Toplam & Toplam \% \\
\hline \multirow{9}{*}{ 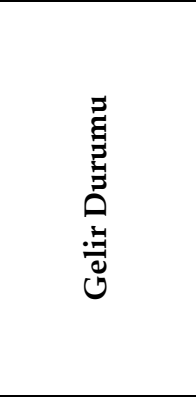 } & Geliri Yok & 5 & 2,48 & 19 & 30,98 & 24 & 11,88 \\
\hline & 1.300 TL'den az & 5 & 2,48 & 4 & 1,98 & 9 & 4,46 \\
\hline & $1301-2000$ & 10 & 4,95 & 11 & 5,45 & 21 & 10,40 \\
\hline & $2001-3000$ & 25 & 12,38 & 30 & 14,85 & 55 & 27,23 \\
\hline & $3001-4000$ & 18 & 8,91 & 17 & 8,42 & 35 & 17,33 \\
\hline & $4001-5000$ & 8 & 3,96 & 11 & 5,45 & 19 & 9,40 \\
\hline & 5.000 TL'den çok & 17 & 8,42 & 14 & 6,93 & 31 & 15,35 \\
\hline & Yanits1z & & & & & 8 & 3,96 \\
\hline & Toplam & 88 & 43,58 & 106 & 74.06 & 202 & 100 \\
\hline
\end{tabular}


Katılımcılardan 112'si kadın, 90'1 ise erkektir. Evli olanların sayısı 122 olup toplama oranları \%60,4'tür. Bununla birlikte boşanmış ve ayrı yaşayanların toplama oranı yaklaşık \%15'tir. Katılımcıların önemli bir bölümü (yaklaşı \%61) 35 ila 54 yaş aralığında olup önlisans, lisans ve lisansüstü eğitim almış bireylerden oluşmuştur. Eğitim durumuna koşut katılımcıların yarıdan fazlası 2001 ila 5.000 TL'den çok aylık gelire sahiptirler.

Katılımcıların gelirleri ile ilgili soruya 8 eksiği dışında yanıt vermiş olmaları özgüven sahibi oldukları biçiminde yorumlanabilir.

Araştırma örnekleminde yer alan katılımcıların IKM ile ilgili doyumlarını oluşturan bağımsız değişkenlere ilişkin aritmetik ortalama ve standart sapmalar Tablo 2 'de görülmektedir.

Tablo 2. Katılımcıların IKM'deki Ürün ve Hizmetlerden Duydukları Memnuniyeti Belirleyen Bağımsız Değişkenler ve Ortalama Değerler

\begin{tabular}{|l|c|c|}
\hline \multicolumn{1}{|c|}{ Değişkenler } & $X$ & SS \\
\hline $\begin{array}{l}\text { Ilgaz Kayak Merkezi (IKM)'nde yeterli sayıda konaklama işletmesi } \\
\text { vardır. }\end{array}$ & 3,32 & 1,048 \\
\hline $\begin{array}{l}\text { IKM'ndeki konaklama işletmelerine ulaştırma araçlarıyla erişim } \\
\text { kolaydır. }\end{array}$ & 3,62 &, 986 \\
\hline $\begin{array}{l}\text { IKM'ndeki konaklama işletmelerine dağıtım kanallarıyla (online- } \\
\text { seyahat acenteleri aracılığıla-doğrudan rezervasyon) erişim kolaydır. }\end{array}$ & 3,83 &, 925 \\
\hline IKM'de konaklama hizmetleri kalitelidir. & 3,69 &, 871 \\
\hline Ilgaz Dağı'nın konaklama fiyatları makuldür. & 3,38 & 1,128 \\
\hline IKM'deki konaklama işletmeleri personelinin hizmeti niteliklidir. & 3,71 &, 951 \\
\hline IKM'de yeterli sayıda yiyecek-içecek işletmesi vardır. & 3,20 & 1,154 \\
\hline IKM'de yiyecek-içecek hizmetleri kalitelidir. & 3,59 &, 946 \\
\hline IKM'nin temizliği niteliklidir. & 3,74 &, 957 \\
\hline IKM'de kayak malzemeleri kolayca temin edilebilmektedir. & 3,88 & 1,005 \\
\hline IKM'deki kayak malzemelerinin kiralama fiyatları makuldür. & 3,28 & 1,297 \\
\hline Ilgaz Dağı telesiyej imkânı yeterlidir. & 3,52 &, 993 \\
\hline $\begin{array}{l}\text { Ilgaz Dağı'nın kayak pistleri farklı zorluk dereceleri açısından } \\
\text { niteliklidir. }\end{array}$ & 3,44 & 1,050 \\
\hline IKM'de çocuklara yönelik aktiviteler yeterlidir. & 3,13 & 1,050 \\
\hline IKM'de alışveriş olanakları yeterlidir. & 2,71 & 1,263 \\
\hline
\end{tabular}

Tablo 2 incelendiğinde ilginç sonuçlara ulaşıldığı görülmektedir. Zira "IKM'ndeki alış-veriş olanakların yeterlidir" 2,71 ortalama ile en düşük, "IKM'nde kayak malzemeleri kolaylıkla temin edilmektedir" ifadesi ise 3,88 ortalama ile en yüksek değeri almıştır. Her iki değer arasında hatırı sayılır bir farkın olduğu söylenebilir. Doyuma yol açan bağımsız değişkenler arasında ikinci en yüksek ortalama 3,88 ile "IKM'ndeki konaklama işletmelerine dağıtım kanallarıla (online-seyahat acenteleri aracılığılyla-doğrudan rezervasyon) erişim kolaydır" ifadesidir. Bu ifade konumundan dolayı fiziksel olarak erişimin çok zor olduğuna inanılan IKM'nin seyahat aracıları tarafından ve/ya doğrudan pazarlama erişilebilirliği açısından oldukça iyi olduğu söylenebilir. 
Diğer yandan IKM'ni ziyaret eden konukların doyumlarına etki eden bağımsız değişkenler içerisinde ikinci en düşük puan 3,13 ortalama ile “IKM'de çocuklara yönelik aktiviteler yeterlidir" ifadesidir. Bu ifadeyi 3,20 ortalama ile "Ilgaz Dağı'nda yeterli sayıda yiyecek-içecek işletmesi vardır"ifadesi izlemiştir.

Araştırmada katılımcıların Ilgaz Kayak Merkezi'nde sunulan ürün ve hizmetlerden almış oldukları doyumu belirleyen bağımsız değişkenlerin etki etmesi olası genel doyum düzeylerini timsal eden bağımlı değişkenlere ilişkin görüşleri de sorgulanmıştır.

Tablo 2'de katılımcların doyumlarına etki eden bağımsız değişkenlerin etkilediği bağımlı değişkenlerin ortalamaları Tablo 3'te verilmiştir.

Tablo 3. IKM'ni Ziyaret Eden Yerli Ziyaretçilerin Genel Olarak Doyumları

\begin{tabular}{|l|c|c|}
\hline \multicolumn{1}{|c|}{ Değişkenler } & X & SS \\
\hline IKM'ndeki konaklama olanaklarından genel olarak memnunum. & 3,69 &, 890 \\
\hline IKM'ndeki yiyecek-içecek olanaklarından genel olarak memnunum. & 3,60 &, 945 \\
\hline IKM'nde otel dışı sunulan etkinliklerden genel olarak memnunum. & 3,39 &, 943 \\
\hline Tatil destinasyonu olarak IKM'nden genel olarak memnun kaldım. & 3,88 &, 805 \\
\hline Tatil destinasyonu olarak IKM'ni tekrar ziyaret edeceğim. & 3,95 &, 816 \\
\hline Tatil destinasyonu olarak IKM'yi yakın çevreme tavsiye edeceğim. & 3,89 &, 867 \\
\hline
\end{tabular}

Tablo 3'teki veriler incelendiğinde katılımcıların IKM'nde sunulan konaklama ürün ve hizmetlerinden duymuş oldukları doyum ortalamasının 3,69 olduğu görülmektedir. Bu değer çok yüksek olmamakla birlikte hatırı sayılır bir memnuniyeti gösterdiği söylenebilir. Katılımcılarım IKM'nde sunulan ürün ve hizmetler içerisinde en düşük memnuniyetin 3,39 ortalama ile otel dışı etkinlikler olduğu açık bir biçimde görülmektedir. IKM'nde sunulan yeme ve içme olanakları ile ilgili doyum ortalaması ise 3,60 olarak hesaplanmıştır. Bu ortalamanın da çok iyi olmadığı ancak "ne memnunum ne de değilim" ile "memnunum" arasında bir değer olduğunu söylemek olanaklıdır. Diğer yandan konukların bir tatil destinasyonu olarak IKM'nden genelde otel dişı etkinlikler, yeme-içme ve konaklamadan duyulan doyumdan daha fazla bir memnuniyet duydukları elde edilen 3,88 ortalama ışığında söylenebilir.

Ilgaz Kayak Merkezi'ni ziyaret eden konukların yeniden ziyaret ve başkalarına tavsiye etme ifadelerine verdikleri yantlar, duyulan doyumdan daha yüksek hesaplanmiştır. "Tatil destinasyonu olarak IKM'ni tekrar ziyaret edeceğim" ifadesine verilen yanıtların ortalaması 3,95'dir. Bu değer tüm doyum ortalamalarının üzerinde olup iyi olarak değerlendirilmektedir. Ayrıca "Tatil destinasyonu olarak IKM'yi yakın çevreme tavsiye edeceğim" ifadesine verilen yanitların ortalamasının da kabul edilebilir bir değer olduğu ifade edilebilir.

Araştırmada ayrıca IKM'nin sunmuş olduğu ürün ve hizmetlerle ilgili katılımcıların duymuş oldukları memnuniyete etki eden etmenlerin sayılarının indirgenerek yeni boyutların ortaya konması amacıyla bir faktör analizi de yapılmıştır. 
Faktör analizi, güvenilir bir anket geliştirilmesi amacına yönelik, bir yapıyı oluşturan ifadelerin o yapıya ait olup olmadıklarına karar vermede kullanılan bir işleve de sahiptir (Coakes \& Steed, 2001). Kaiser-Meyer-Olkin (KMO) örneklem yeterliliği ölçüsü kabul edilebilir değer olan 0,6'dan yüksek olarak 0,866 bulunmuştur. Barlett Küresellik Testi değeri 926,398 ve önem düzeyi (Sig.) ise 0,000 olarak bulunmuştur. Araştırma verilerinin normal dağılıp dağılmadığı ilgili testler yapılmıştır. Test sonuçların skewness ve kurtosis değerlerinin olması gereken değerler arasında olduğunu ortaya koymuştur.

Faktör analizi çerçevesinde uygulanan işlemler sonucunda ölçekte yer alan 15 ifadeden dört grupta kümelenen yeni bir yapı elde edilmiştir. Yeni yapıda yer alan faktörler "Kayak Olanakları, Rekreasyon Olanakları, Ürün ve Hizmetlerin Kalitesi, Erişilebilirlik" olarak adlandırılmıştır. Elde edilen yeni yapı toplam varyansın \% 61,354'ünü açıklamaktadır. Faktör analizi için özdeğeri 1, faktör yükü 0,40'ın üzerinde olan değerlerin temel alındığ1 ve Temel Bileşenler Analizi (Principal Components)'nin Varimax döndürmesi işe koşulmuştur. Döndürme sonucu hiçbir ifade eksiltilmemiştir. Faktör analizi sonuçları Tablo 4.'te verilmiştir.

Faktör analizinde oluşan yeni yapıda ilk küme içerisinde yer alan ve "Kayak Olanakları" olarak adlandırılan faktör 5 ifade ile toplam varyansın \%16,540'1nı açılamaktadır. Bu sonuç hiç de sürpriz değildir. Zira ziyaretçiler IKM'ne öncelikle kayak yapma amaciyla gelmektedirler. Küme içerisinde yer alan "IKM"nde kayak malzemeleri kolayca temin edilebilmektedir" ifadesi 0,777 faktör yükü ile ziyaretçilerin en çok önem atfettikleri değişken olarak kabul edilebilir. Bu gerçekleşme konukların kayağa verdikleri önemin bir sonucu oluşmuştur denebilir. Bu ifadeyi 0,706 faktör yükü ile "IKM'nde kayak malzemelerinin kiralama maliyetleri makuldür" ifadesi izlemiştir. $\mathrm{Bu}$ boyut altında kümelenen "IKM'de telesiyej olanakları yeterlidir" ifadesi 0,573 faktör yükü ile kayak olanaklarının önemini teyit eden bir başka unsur olarak görülmektedir. Kayak olanakları faktörü altında kümelenen "IKM'nın kayak pistleri farklı zorluk dereceleri açısından niteliklidir " ifadesi ise en düşük değere sahip olan ifadedir. 
Tablo 4. Faktör Analizi Sonuçları

\begin{tabular}{|c|c|c|c|}
\hline 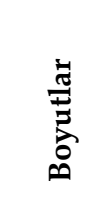 & Değişkenler & 施 & 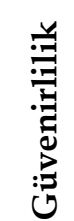 \\
\hline \multirow{5}{*}{ 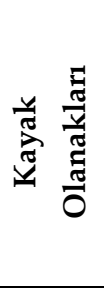 } & 10. IKM"nde kayak malzemeleri kolayca temin edilebilmektedir. & ,777 & \multirow{5}{*}{,757 } \\
\hline & 11. IKM'ndeki kayak malzemelerinin kiralama fiyatları makuldür. & ,706 & \\
\hline & 9. Genel olarak IKM'nın temizliği niteliklidir. & 682 & \\
\hline & 12. IKM telesiyej imkânı yeterlidir. &, 573 & \\
\hline & $\begin{array}{l}\text { 13. IKM'nın kayak pistleri farklı zorluk dereceleri açısından } \\
\text { niteliklidir. }\end{array}$ & ,436 & \\
\hline \multirow{3}{*}{ 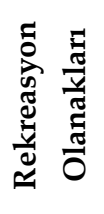 } & 15. IKM'nda alışveriş olanakları yeterlidir. & ,782 & \multirow{3}{*}{,734 } \\
\hline & 14. IKM'nda çocuklara yönelik aktiviteler yeterlidir. & 7,33 & \\
\hline & 7. IKM'nda yeterli sayıda yiyecek-içecek işletmesi vardır. & 721 & \\
\hline \multirow{3}{*}{ 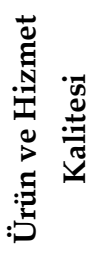 } & 6. IKM'ndaki konaklama işletmeleri personelinin hizmeti niteliklidir. & 800 & \multirow{3}{*}{,788 } \\
\hline & 4. IKM'nda konaklama hizmetleri kalitelidir. & ,760 & \\
\hline & 8. IKM'nda yiyecek-içecek hizmetleri kalitelidir. & ,669 & \\
\hline \multirow{4}{*}{ 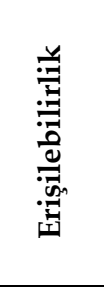 } & $\begin{array}{l}\text { 2. IKM'ndaki konaklama işletmelerine fiziksel (ulaştırma araçlarıyla) } \\
\text { erişim kolaydır. }\end{array}$ & 846 & \multirow{4}{*}{ 671 } \\
\hline & $\begin{array}{l}\text { 3. IKM'ndaki konaklama işletmelerine dağıtım kanallarıyla(online- } \\
\text { seyahat acenteleri aracılığıla-doğrudan rezervasyon) erişim kolaydır. }\end{array}$ & ,615 & \\
\hline & 1. IKM'nda yeterli sayıda konaklama işletmesi vardır. &, 576 & \\
\hline & 5. IKM'nın konaklama fiyatları makuldür. & 446 & \\
\hline
\end{tabular}

Kaiser-Meyer-Olkin Uygunluğu Testi: ,866Barlett Küresellik Testi:926,398Anlamlılık: ,000

Faktör analizi sonucu elde edilen ikinci boyuta "Rekreasyon Olanakları" adı verilmiştir. Bu boyut altında kümelenen ifade sayısı üçtür. Bu ifadeler içinde "IKM'nda alışveriş olanakları yeterlidir" ifadesi IKM'ni ziyaret eden konukların alış veriş olanaklarını kayak merkezi doyumunda önemli bir konuma yerleştirdikleri biçiminde değerlendirilebilir. Rekreasyon olanakları boyutu altında kümelenen ikinci ifade "IKM'nda çocuklara yönelik aktiviteler yeterlidir" ifadesidir. Bu ifadenin doyumu belirleyen etmenlerden biri olarak belirmesi IKM'ni ziyaret eden konukların çocukları ile birlikte tatile çıktıkları ve onlara yönelik seçeneklerin varlığını doyum açısından önemsedikleri biçiminde yorumlanabilir. Nitekim katılımcıların demografik bilgileri incelendiğinde bekâr olanların toplama oranının yalnızca \%24,25, kalan \%76,75'lik değerin \%60,4'ünün evli, \%11,88'inin boşanmış olduğu görülecektir. Bu değerler evli ya da geçmişte evli olup günümüzde bu durumunu sonlandırmış olanların çocuk sahibi olabilecekleri olasılığını ve çocuklara yönelik rekreasyon olanakların önemini ortaya koymaktadır. 
Faktör analizi sonucu elde edilen üçüncü boyut "Ürün ve Hizmet Kalitesi" olarak adlandırılmıştır. Bu boyut altında kümelenen üç ifadeden birincisi 0,800 faktör yükü ile "IKM'ndaki konaklama işletmeleri personelinin hizmeti niteliklidir" ifadesidir. İkinci ifade ise 0,760 faktör yükü ile "IKM'nda konaklama hizmetleri kalitelidir" ifadesidir. Bu boyut altında kümelenen son ifade ise 0,669 faktör yük değeri ile "IKM'nda yiyecek-içecek hizmetleri kalitelidir" ifadesidir. Bu ifadeler IKM'nde tatil yapan konuklarm kaliteye yönelik duyarlılıklarının somut bir göstergesi olarak kabul edilebilir.

Faktör analizi sonucunda elde edilen indirgenmiş dördüncü boyut "Erişilebilirlik" başlığı altında isimlendirilmiştir. Bu faktör altında kümelenen ifadelerden birincisi 0,846 faktör yükü ile "IKM'ndaki konaklama işletmelerine fiziksel (ulaştırma araçlarıyla) erişim kolaydır" ifadesidir. İkinci ifade ise "IKM'ndaki konaklama işletmelerine dağıtım kanallarıyla (online-seyahat acenteleri aracılı̆̆ıyla-doğrudan rezervasyon) erişim kolaydır" ifadesidir. Bu ifadenin faktör yükü 0,615 olarak hesaplanmıştır. Bu ifadeyi 0, 576 faktör yüküyle "IKM'nda yeterli sayıda konaklama işletmesi vardır" ve 0,446 faktör yükü ile "IKM'nın konaklama fiyatları makuldür" ifadeleri izlemiştir.

Dördüncü boyut altında kümelenen ifadelerin bir varış noktasının turistik ürün açısından erişilebilir olması gerekliliği ile örtüştüğü ifade edilebilir. Nitekim bir ülkenin, bölge ve/ya turistik varış noktasının öncelikle fiziksel olarak ulaşılabilir, aynı zamanda dolaylı ve doğrudan dağıtım kanalları ile de erişilebilir olması (Kozak, Kozak ve Kozak, 2017) temel bir koşul olarak kabul edilmektedir. Bu koşulların yanı sıra turistik varış noktalarının potansiyel tüketiciler tarafından sahip olunan ekonomik yeterlik bakış açısıyla da erişilebilir olması Ilgaz Kayak Merkezi'nde tatil yapmayı tercih eden yerli turistlerin doyumlarını belirleyen bir boyut olarak ortaya çıkması sonucunu doğurmuştur denebilir.

Çalışmada araştırmacıların ilgili yazında yaptıkları derinlemesine inceleme sonucunda geliştirmiş oldukları ölçeğin güvenirliği de ölçülmüştür. Yapılan Cronbach's Alfa analizi sonucunda ölçeğin güvenilirliği 0,877 olarak bulunmuştur. Diğer yandan faktör analizi sonrasında elde edilen dört faktör, küme oluşturan ifadelerin yer aldığı yapı bozulmadan ayrıca güvenilirlik analizine tabi tutulmuş ve değer 0,796 olarak hesaplanmıştır. Hesaplanan güvenirlik değerlerinden hareketle araştırma ölçeğinin oldukça yüksek bir güvenilirliğe sahip olduğu ifade edilebilir (Nunnally \& Bernstein 1994; Hair, William, Bary \& Anderson, 1996). Güvenirlik hesaplaması ile ilgili değerler Tablo 5'te verilmiştir.

Tablo 5. Araştırmada Kullanılan Ölçeğin Güvenirlik Analizi

\begin{tabular}{|c|c|c|}
\hline Cronbach Alfa Katsayısı & $\begin{array}{c}\text { Standartlaştırılmış Maddeler } \\
\text { Cronbach Alfa Katsayısı }\end{array}$ & $\begin{array}{c}\text { İfade / Faktör } \\
\text { Sayısı }\end{array}$ \\
\hline, 874 &, 877 & 15 \\
\hline \multicolumn{2}{|c|}{ Faktör Analizi Sonrası (Kayak Olanakları, Rekreasyon olanakları, Ürün ve } \\
hizmetlerin kalitesi, Erişilebilirlik)
\end{tabular}




\section{TARTIŞMA, SONUÇ VE ÖNERILER}

Kârlılık ve kâr enbüyüklemesi (maksimizasyonu) işletmeler açısından varlıklarını sürdürebilmek adına her zaman önde gelen hedefler olarak sunulmaktadır. $\mathrm{Bu}$ nedenler işletmeler açısından memnun müşteriler kitlesi yaratmak ve rakipler karşısında önemli bir avantaj yakalamak anlamına gelmektedir. Bunu başaran ve değişen pazar koşullarına uyum sağlayabilen işletmeler orta ve uzun vadeli rekabet üstünlüğü ve kârlılık hedefine ulaşmaktadırlar (Day, 1994).

Turizm ve ağırlama işletmelerinin varlıklarını sürdürebilmeleri de hizmet verdikleri konukların istem ve beklentilerini (en azından) karşılayan bir tüketici doyumu sağlamaları halinde olanaklıdır (Tutuncu, 2017). Bu öngörü “Beklentilerin Karşılanması Teoremi"'ni ortaya atan Oliver (1980) ve birçok diğer yazar tarafından doğrulanmış bulunmaktadır (Day, 1994; Tütüncü, 2001; Çiçek ve Doğan, 2009; Lankton, \& McKnight, 2012; Şahin ve Şen, 2017).

Günümüzde müşteri memnuniyetinin işletmelerin başarısının en önemli koşulu olarak değerlendirilmesinin temelinde memnun tüketicilerin işletmeden hizmet almayı sürdürmelerinin yanı sıra başkalarına tavsiye etmeleri gerçeği yatmaktadır. Bu öngörüye koşut bu çalışmada Ilgaz Kayak Merkezi'ni ziyaret eden yerli turistlerin almış oldukları ürün ve hizmetlerden duymuş oldukları memnuniyet ya da memnuniyetsizlik ölçülmek istenmiştir. Çalışmada memnuniyet ya da memnuniyetsizliğe koşut yerli turistlerin IKM'ni yeniden ziyaret ve başkalarına tavsiye konularındaki tutumları da ölçülmüştür. Araştırma da ayrıca konukların genel profilleri de ortaya konmuştur. Tüm bunlara ek olarak araştırmada görüşüne başvurulan yerli turistlerin memnuniyetlerine etki eden unsurlar keşfedici faktör analizi ile saptanmıştır.

Araştırma bulguları Ilgaz Kayak Merkezinde tatil yapan yerli turistlerin iyi eğitimli, 35 ila 54 yaş aralığında, genellikle evli, kadınların erkeklere göre biraz daha çok olduğunu ortaya konmuştur. Yerli ziyaretçilerin genellikle serbest meslek erbabı oldukları, buna karşın çok yüksek gelire sahip olmadıkları saptanmıştır.

Sonuç olarak araştırma bulguları Ilgaz Kayak Merkezi'nden tatil yapan yerli ziyaretçilerin merkezde almış oldukları yeme-içme, konaklama ve rekreasyon hizmetlerinden genel olarak hafif düzeyde bir memnuniyete sahip olduklarını ortaya koymuştur. Nitekim katılımcılara yöneltilen ve aynı zamanda araştırmada yanıtı aranan; "IKM'ni ziyaret edenlerin; i. genel anlamda doyum düzeyleri, ii. yeme-içme, iii. konaklama, iv. rekreasyon olanaklardan doyum düzeyleri nedir? Sorularına verilen yanıtlar bu ifadeyi doğrulamaktadır. Buna karşın IKM ziyaret eden yerli turistlerin yeniden ziyaret etme ve başkalarına tavsiye etme konularında oldukça istekli oldukları sonucuna varılmıştır.

Araştırmada ayrıca Ilgaz Kayak Merkezi'ni ziyaret eden konukların doyumlarını belirleyen dört faktörün/boyutun olduğunu ortaya konmuştur. Bu boyutlar içerisinde ilk sırayı kayak olanakları olarak adlandırılan faktör almıştır. Bu faktörü rekreasyon olanakları adı verilen boyut izlemiştir. Yerli turistlerin Ilgaz Kayak 
Merkezi'nde sunulan olanaklarla ilgili doyumlarını belirleyen üçüncü faktör ise ürün ve hizmetlerin kalitesi olarak adlandırılmıştır. Doyumu belirleyen son faktör ise erişilebilirlik faktörüdür.

Araştırma bulguları Gencer, Demir ve Aycan (2008) tarafından yürütülen "Kayak Merkezlerindeki Spor Turistlerinin Hizmet Kalitesi Algıların Etkileyen Değişkenler" adlı çalışmasında elde edilen sonuçlarla büyük benzerlik göstermektedir. Araştırmacıların Bursa'nın Uludağ Kayak Merkezi'nde 181 katılımcı ve 4 uzman görüşüne başvurarak yürüttükleri çalışmalarında turistlerin doyumlarına etki eden 5 faktör belirlenmiştir. Bunlar önem sırasına göre "kayak eğitmenleri, kayak pist ve malzemeleri, oteller ve çalışanları, ortam ve eğlence"dir. Gencer ve arkadaşlarının çalışmalarında turistlerinin hizmet kalitesi algılarını etkileyen bileşenler arasında kayak pist ve malzemelerinin en önemli bileşen olduğu saptanmıştır (Gencer, Demir ve Aycan, 2008).

Benzer bir sonuç Ayaz ve Apak (2017) tarafından 2015 yılında 480 katılımcı ile yürütülen "Kış Turizmine Katılan Yerli Turistlerin Seyahat Motivasyonları ve Seyahat Memnuniyetleri" adlı çalışmada elde edilmiştir. Yazarlar katılımcıların memnuniyetlerini belirleyen etmenleri "eğitmen, pist, ulaşım, güvenlik, konaklama ve alışveriş" olarak adlandırdıkları beş faktörlü bir yapı ile ifade etmişlerdir (Ayaz ve Apak, 2017). Bu yapı içerisinde yer alan eğitmen, pist, ulaşım faktörlerinin yanı sıra konaklama ve alışveriş faktörünü oluşturan değişkenlerle bu araştırmada elde edilen kayak olanakları, rekreasyon olanakları, ürün ve hizmet kalitesi ve erişilebilirlik faktörlerini oluşturan değişkenler örtüşmektedir.

Genelde kış, özelde ise kayak turizminin yaratmış olduğu niş pazar fırsatlarına rağmen konuya yönelik araştırmacı, uygulamacı ve yönetici ilgisinin çok az olduğu söylenebilir. Zira kayak turistlerinin doyumlarını belirleyen etmenler ve bu etmenlerin ışığında elde edilen doyuma yönelik araştırmalar yok denecek kadar azdır. Bu nedenle ilgili yazında önemli bir boşluğun var olduğu ifade edilebilir. Bu ifadeye koşut Ilgaz Kayak Merkezi'ni tercih ederek kayak tatili yapan yerli turistlerin memnuniyetlerini belirleyen faktörler ve tatilci doyumu ile ilgili çalışmaların hemen hemen hiç yapılmadığını söylemek olanaklıdır. Bu açıdan bakıldığında bu çalışma Ilgaz Milli Parkı içerisinde yer alan merkezde kayak tatili yapan yerli turistlerin doyumlarına etki eden etmenleri ve elde edilen doyumu ortaya koyan ilk çalışmadır.

Çalışma sonuçları araştırmacılar ve Ilgaz Kayak Merkezi Yönetimi'nin yanı sıra bu merkezde turistik ürün ve hizmet sunan işletme yöneticilerine bir takım kuramsal ve uygulama görevleri yüklemektedir. Örneğin tatilcilerin IKM'nde yiyecek ve içecek başta olmak üzere alışveriş ve benzeri ürün ve hizmet sunan işletmelerin nicel olarak yeterli olmadığı yönündeki ifadeleri gerçekçidir. Zira araştırmacılar uzun sayılabilecek bir süredir hem rekreasyonel hem de profesyonel (araştırma ve inceleme gezileri) amaçlarla IKM'ni sıkça ziyaret etmekteler, doğrudan ve katılımcı gözlemlerle var olan yeme içme, alışveriş ve diğer rekreasyon olanakların yeterli olmadığını görebilmektedirler. Oysaki kayak turisti görece varlıklı bireylerden oluşan bir profil ortaya koymakta ve sayılan ürün ve hizmetleri sunan işletmelere yönelik hatırı sayılır 
bir potansiyel talebi bünyelerinde taşımaktadırlar. Bu ifadelere koşut Ilgaz Dağı Milli Parkı (IDMP) yönetimi başta olmak üzere Kastamonu ve Çankırı valilikleri ile ilgili birimleri IKM'nde yeme-içme, alışveriş, eğlence ve diğer rekreasyon alanları oluşturma konusunda inisiyatif üstlenmeleri gerektiğine inanılmaktadır. Bu çabaların yanı sıra hali hazırda var olan gerek kamuya ait ağırlama işletmelerinin, gerekse de özel sektöre ait kâr amacı güden işletmelerin var olan tesislerinde alışverişe yönelik mağazalar açmaları, olanaklı yerlere nitelikli yeme içme ve eğlence üniteleri eklemeleri önerilmektedir.

$\mathrm{Bu}$ çalışma kendi kısıtları içerisinde değerlendirilmelidir. Bu nedenle eksik yönleri bulunmaktadır. Örneğin araştırmanın 2017 yılının 28 Ocak ila 05 Şubat tarihleri arasında IKM'ni ziyaret eden sınırlı sayıda ziyaretçi ile yapılmış olması önemli bir kısıt olarak görülmektedir. Konuya ilgi duyan araştırmacıların kayak mevsiminin diğer zamanlarında benzer çalışmaları yürütmelerinin bilgi birikimine önemli bir katkı sağlayacağına inanılmaktadır. Ayrıca gerek IDMP yönetiminin, gerek Kastamonu ve Çankırı İl Özel İdaresinin, gerekse de halen var olan işletme yönetimlerinin makro planlamalarının ne olduğunu saptamaya yönelik bilimsel araştırmaların sürdürülebilir turizm açısından yararlı olacağı ifade edilebilir. Son olarak bir türlü bitirilemeyen Yurduntepe pistinin hizmete açılarak daha fazla sayıda kayakçının bölgeye çekilmesi potansiyelinin önünün açllması önerilmektedir.

\section{KAYNAKÇA}

Ahvenainen, J. (2013). Sport Tourism and Destination Marketing. Case: Innsbruck and Lahti. Unpublished Thesis of Degree Programme in Tourism, Laurea University of Applied Sciences, Vantaa.

Albayrak, T. ve Caber, M. (2011). Önem-Performans Analizi: Destinasyon Yönetimine Dair Bir Örnek. Ege Akademik Bakış Dergisi, 11(4),627-638.

Anderson, W. E. \& Sullivan, W. M. (1993) The Antecedents and Consequences of Customer Satisfaction for Firms. Marketing Science, 12(2), 125-143.

Arat, T., Karaman, A. ve Harbali, H. (2015). Turistik Destinasyonlarda Hizmet Kalitesi Üzerine Bir Araştırma, Pamukkale Üniversitesi, İşletme ve Bilişim Yönetimi Dergisi, 2(2), 1-14.

Arıkan, I.S. (2016). Turist Çekim Merkezinde Hizmet Kalitesinin Önem Performans Analizi İle Değerlendirilmesi: Ölüdeniz Tabiat Parkı Örneği, 17. Ulusal Turizm Kongresi Bildiriler Kitabı, 20-23 Ekim, Muğla, 1025-1034.

Arslan, R. (2008). Türk Bankacılık Sisteminde Rekabet Stratejileri ve Yayılım Süreci, Uşak Üniversitesi Sosyal Bilimler Dergisi, 1(2), 128-141.

Ayaz, N. ve Apak, Ö. C.(2017). Kış Turizmine Katılan Yerli Turistlerin Seyahat Motivasyonları ve Seyahat Memnuniyetleri, Erzincan Üniversitesi Sosyal Bilimler Enstitüsü Dergisi (IV), 79-94.

Aydoğdu, A. (2005). Otel İşletmelerinde Hizmet Kalitesi ve Müşteri Doyum İlişkisi, Yayınlanmamış Yüksek Lisans Tezi, Dokuz Eylül Üniversitesi Sosyal Bilimler Enstitüsü, İzmir. 
Aydoğdu, A. (2012). Kastamonu'nun Doğal Zenginliklerinin Turistik Ürün Bakış Açısıyla İrdelenmesi, Kastamonu'nun Doğal Zenginlikleri Sempozyumu, 16-17 Ekim, Kastamonu, 161-185.

Aydoğdu, A. (2016). Turistler Arası Etkileşim, Turizmin Sosyal Psikolojik Dinamikleri (içinde editörler; Erol Duran ve Cumhur Aslan), Paradigma Akademi, İstanbul.

Aydoğdu, A.,Çitoğlu A.ve Bayraktar, O.Y. (2016). Abana Turizminin Sorunları ve Çözüm Önerileri, I. Uluslararası Abana Sempozyumu,20-21 Mayıs, Kastamonu, 86-99.

Burakowski, E., \& Magnusson, M. (2012). Climate impacts on the winter tourism economy in the United States. Natural Resources Defense Council, New Hemshire.

Büyüköztürk, Ş. (2002). Faktör analizi: Temel kavramlar ve ölçek geliştirmede kullanımı. Kuram ve Uygulamada Ĕ̆itim Yönetimi, 32(32), 470-483.

Coakes, J. S. \& Steed, G. L. (2001). SPSS: Analysis without Anguish: Version10.0 for Windows. Brisbane: John Wiley \& SonsAustralia, Ltd.

Çakıcı, A.C. ve Özdamar, M. (2016). Üniversite Düzeyinde Turizm Eğitimi Alan Öğrencilerin Kendini Beğenmişlikleri İle Hizmet Yönelimleri Arasındaki İlişki, 17. Ulusal Turizm Kongresi Bildiriler Kitabı, 20-23 Ekim, Muğla, 749-760.

Çiçek, R.,\& Doğan, İ. C. (2009). Müşteri Memnuniyetinin Artırılmasında Hizmet Kalitesinin Ölçülmesine Yönelik Bir Araştırma: Niğde İli Örneği. Afyon Kocatepe Üniversitesi İ̈BF Dergisi, 11(1), 199-218.

Duman, T.ve Öztürk, A.B.(2005). Yerli Turistlerin Mersin Kızkalesi Destinasyonu ve Tekrar Ziyaret Niyetleri ile İlgili Algılamaları Üzerine Bir Araştırma, Anatolia: Turizm Araştırmaları Dergisi, 16(1),ss.9-23.

Ekiz, E. ve Ölçer, C. (2016). Algılanan Hizmet Kalitesinin Toplam Hizmet Kalitesi ve Müşteri Memnuniyetine Etkileri: Suudi Havayolları Üzerine Bir Araştırma, 17. Ulusal Turizm Kongresi Bildiriler Kitabı, 20-23 Ekim, Muğla, ss.1375-1383.

Fuller, D., Wilde, S., Hanlan, J. ve Mason, S. (2007). Destination Decision Making in Tourism Regions on Australia's East Coast, Flinders Business School Research Paper Series, ss. 7-27.

Gencer, R. T. \& Demir, C. (2008). Kayak Merkezlerindeki Spor Turistlerinin Hizmet Kalitesi Algilarini Etkileyen Degiskenler. Ege Academic Review, 8(2), 437-450.

Güzel, Ö. F. (2010). Turistik Ürün Çeşitlendirmesi Kapsamında Yeni Bir Dinamik: İnanç Turizmi, Süleyman Demirel Üniversitesi Vizyoner Dergisi, 2(2), 87-100.

Hair, J. F., William, C. B, Barry, J. B. ve Anderson R. E. (1996). Multivariate Data Analysis. Prentice Hall, New Jersey.

Işın, A. (2012). Yerli ve Yabancı Turistlerin Otel İşletmelerinde Sunulan Hizmet Kalitesi Algılamalarının Müşteri Sadakati Üzerine Etkisi, Yayınlanmamış Yüksek Lisans Tezi Gazi Üniversitesi, Ĕ̆itim Bilimleri Enstitüsü, Ankara.

Karasar, N.(2005). Bilimsel Araştırma Metodu,Hacettepe Taş Kitapçılık, Ankara.

Kaşl1, M., İlban, M.O., Şahin, B. (2009). Modern Pazarlama Stratejileri: AB ve Türk Turizmi, Electronic Journal of Social Sciences, 8(27), 79-98.

Kılıçhan, R. (2012). Kruvaziyer Gemilerin Yiyecek İçecek Departmanlarında Hizmet Kalitesi, Müşteri Memnuniyeti Ve Müşteri Sadakati İlişkileri: Ketchikan, Juneau Ve Skagway 
Limanlarında Bir Araştırma, Nevşehir Hacı Bektaş Veli Üniversitesi,Turizm İşletmeciliği Ana Bilim Dalı Yayınlanmamış Yüksek Lisans Tezi, , Nevşehir.

Kozak, N., Kozak, M. ve Kozak, M. A. (2017). Genel Turizm: İlkeler Uygulamalar, Detay Yayıncilık, Ankara.

Kuşluvan, S. ve Eren, D. (2011). İş görenlerin Kişilik Özelliği Olarak Hizmet Verme Yatkınlığı ve Ölçümü: Bir Literatür Taraması, Anatolia: Turizm Araştırmaları Dergisi, 22(2), 139-153.

Lankton, N. K., \& McKnight, H. D. (2012). Examining two expectation disconfirmation theory models: assimilation and asymmetry effects. Journal of the Association for Information Systems, 13(2), 88.

McDowall, S. \& Ma, E. (2010). An Analysis of Tourists' Evaluation of Bangkok's Performance, Their Satisfaction, and Destination Loyalty: Comparing International Versus Domestic Thai Tourists, Journal of Quality Assurance in Hospitality \& Tourism, 11(4), 25-38.

Millan, A., Esteban, A. (2004). Development Of A Multiple-İtem Scale For Measuring customer Satisfaction In Travel Agencies Services, Tourism Management, 25(5), 533-546.

Nunnally, J.C. \& Bernstein, I.H. (1994). Psychometric Theory, 3rd. Edn, McGraw-Hill, New York.

Oliver, R.L. (1980). A cognitive model of the antecedents and consequences of satisfaction decisions, Journal of Marketing Research (17), 460-469.

Piercy, N. \& Ellinger, A.(2015). Demand- and Supply-Side Cross-Functional relationships: An Application of Disconfirmation Theory, Journal of Strategic Marketing, 23(1), 49-71.

Ritchie, J.R.B. ve Crouch, I.G. (2000). The Competitive Destination: A Sustainability Perspective, Tourism Management, (21), 1-7.

Saltık, Z. (2016). Stresin İşgören Performansına ve İşten Ayrılma Niyetine Etkisi: Konaklama İşletmelerinde Bir Uygulama. Nevşehir Hacı Bektaş Veli Üniversitesi, Turizm İşletmeciliği Ana Bilim Dalı,Yayınlanmamış Yüksek Lisans Tezi, Nevşehir.

Şahin, A. ve Şen, S. (2017). Hizmet Kalitesinin Müşteri Memnuniyeti Üzerine Etkisi, Uluslararası Sosyal Araştırmalar Dergisi, 10(52), 1176-1184.

Şirin, M. E. ve Aksu, M. (2016). Otel İşletmelerinde Hizmet Kalitesinin Müşteri Memnuniyeti, Tekrar Satın Alma ve Tavsiye İsteği Üzerine Etkisi: Trabzon Ortahisar Örneği, Karabük Üniversitesi, SBE Dergisi, 6(2), 530-544.

Tutuncu, O. (2017). Investigating the accessibility factors affecting hotel satisfaction of people with physical disabilities. International Journal of Hospitality Management, 65, 29-36.

Tütüncü, Ö. (2001), Yiyecek-İçecek İşletmelerinde Müşteri Tatminin Ölçülmesi, 1. Baskı, Turhan Kitabevi, Ankara.

Yıldırım C. (1966). Eğitimde Araştırma Metotları, Akyıldız Matbaası, Ankara.

Yoon, Y. \& Uysal,M. (2005). An Examination of Effects of Motivation and Satisfaction on Destinastion Loyalty: A Structural Model, Tourism Management (26), 45-56.

Zengin, B. ve Bilgiçli, İ. (2016). Turizm İşletmelerinde Rekabet Ve Rekabet Gücünü Etkileyen Unsurlar Üzerine Kavramsal Bir İnceleme, 17. Ulusal Turizm Kongresi Bildiriler Kitabı, 2023 Ekim, Muğla, 832-843. 


\section{İnternet Kaynakları}

Kalkınma Bakanlığı. (2013). T.C. Kalkınma Bakanlığı, İllerin ve Bölgelerin Sosyo-ekonomik Gelişmişlik Siralamasi

Araştırması, http://www.ab.gov.tr/files/ardb/evt/2_turkiye_ab_iliskileri/2_2_adaylik_sureci/2_2_8_di ger/tckb_sege_2013.pdf, 10.02.2017 tarihinde erişilmiştir.

Kastamonu Belediyesi. (2015). http://kastamonu.bel.tr/v2/wp-content/uploads/2016/05/stratejikplan-2015-2019.pdf 08.02.2017 tarihinde erişilmiştir.

Ski Canada. (2015). The \#1 Winter Activity with $\$ 800$ Million in Economic Benefits, https://www.skicanada.org/the-1-winter-activity-with-800-million-in-economicbenefits/, 08.03.2018 tarihinde erişildi.

UNWTO.(2017). Tourism Highlights 2017, http://mkt.unwto.org/publication/unwto-tourismhighlights, 04.03.2018 tarihinde erişilmiştir.

UNWTO. (2018). 2017 International Tourism Results: The highest in seven years, http://media.unwto.org/press-release/2018-01-15/2017-international-tourism-resultshighest-seven-years, 04.03.2018 tarihinde erişilmiştir. 